DOI: 10.15393/j10.art.2019.4021

УДК 821.161 .1

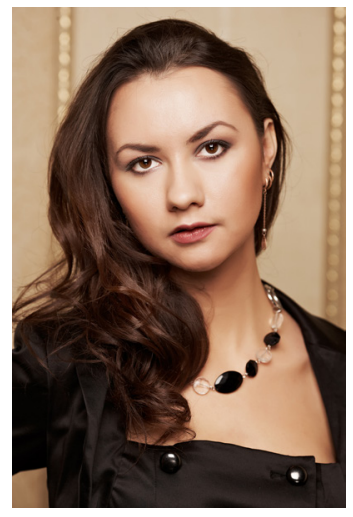

А. В. Бурмистрова

Институт мировой литературьь, Российская академия наук (Москва, Российская Федерация) alina-art@autorambler.ru

\title{
Инсценировки романов Достоевского (первые опыты)
}

Аннотация. В статье рассматривается проблема зарождения и формирования так называемого «театра Достоевского». Исследование выполнено после изучения статей из столичной и провинциальной периодики, посвященных инсценировкам произведений Достоевского и рецепции его творчества в 1880-1890-е гг. Многие из них, ранее не рассматривавшиеся исследователями, посвящены сценичности романов писателя. Обзор и подробный анализ этих источников, впервые вводимых в научный оборот, составляет новизну работы. Особый интерес представляют материалы из архива ГЦТМ им. А. А. Бахрушина - суфлерский экземпляр инсценировки «Преступления и наказания» Дельера и пьеса Крылова и Сутугина по мотивам романа «Идиот» для сцены московского Малого театра и петербургского Александринского театра по роману «Идиот».

Ключевые слова: Достоевский, театр, инсценировка, рецепция, традиция, периодика, критика, архив

Об авторе: Бурмистрова Алина Валентиновна - кандидат филологических наук, Институт мировой литературы им. А. М. Горького Российской академии наук (ул. Поварская, 25а, г. Москва, 121069, Российская Федерация), корреспондент газеты Союза кинематографистов «СК-Новости» (ул. Васильевская, дом 13, стр. 1, г. Москва, Российская Федерация, 123056)

Дата поступления: 17.01.2019

Дата публикации: 14.09.2019

Для цитирования: Бурмистрова А. В. Инсценировки романов Достоевского (первые опыты) // Неизвестный Достоевский. - 2019. - № 3. - C. 96-115. DOI: 10.15393/j10. art.2019.4021 


\section{Достоевский и театр: введение в тему}

Федор Михайлович Достоевский не только один их самых значительных русских авторов, но также один из самых сценичных. Несмотря на то, что Достоевский не был драматургом, инсценировки его романов вот уже более ста лет идут на российской и мировой сцене наряду с пьесами Шекспира и Чехова.

Однако у истоков творчества писателя находились именно драматические опыты. По свидетельству друга молодости писателя, доктора А. Е. Ризенкампфа (в пересказе О. Ф. Миллера), в 1840-1842 гг. Достоевский трудился над двумя историческими драмами - «Марией Стюарт» и «Борисом Годуновым»: «Что касается первого сюжета, то Федор Михайлович <...> продолжал ревностно им заниматься и в 42 г., чему способствовало сильное впечатление, произведенное на него в роли Марии Стюарт немецкою трагическою актрисою Лилли Лёве. Достоевский хотел обработать эту трагическую тему по-своему, для чего тщательно принялся за приготовительное историческое чтение. Куда девались наброски его “Марии Стюарт”, а равно и “Бориса"- остается неизвестным».

Американский славист Роберт Л. Бэлнеп писал о драматургических истоках творчества Достоевского: «Драматургия всегда привлекала Достоевского. <...> Роман "Преступление и наказание" первоначально также был задуман в виде драмы. К счастью, писатель не довел этот план до конца - вполне вероятно, что драма вобрала бы в себя все недостатки “Власти тьмы” и “Воскресения" Льва Толстого, не обладая и малой долей их достоинств. Но как у Толстого замысел романа о декабристах переродился в роман “Война и мир”, так и составленный Достоевским план мелодрамы послужил основой “Братьев Карамазовых” " [Бэлнеп: 93].

Известно, что за десять дней до смерти в разговоре с А. С. Сувориным, который поинтересовался, отчего Достоевский никогда не писал драмы при таком великом мастерстве написания монологов, Федор Михайлович посетовал: «У меня какой-то предрассудок насчет драмы. Белинский говорил, что драматург настоящий должен начинать писать с двадцати лет. У меня это и засело в голове. Я все не осмеливался. Впрочем, нынешним летом я надумывал один эпизод из “Карамазовых" обратить в драму»². К сожалению, этому замыслу не суждено было воплотиться.

По мнению И. Л. Волгина, «роман Достоевского <“Идиот”> (как целое) абсолютно неподъемен ни для сцены, ни для экрана. <..> зритель рискует заблудиться в этом чудовищном лабиринте человеческих отношений в подвалах, башенках, флигелечках, чуланах, пристройках и т. д.» [Волгин]. Однако и режиссеры XIX-XX вв., и современные, обращались и продолжают обращаться к творчеству Ф. М. Достоевского и инсценировать его произведения, сохраняя авторское слово или опираясь на собственную концепцию. 
Опыт этих постановок очень важен, поскольку позволяет говорить о «театре Достоевского» как особой художественной системе.

Тема сценичности романов Достоевского давно в центре внимания критики, но она до сих пор не получила глубокого теоретического осмысления. Б. Н. Любимов так обозначил эту проблему: «...судьба Достоевского в театре, судьба в своем роде единственная. Повышенный интерес театров к Достоевскому нельзя объяснить только философской и социальной значимостью его созданий. Проникновению произведений Достоевского в репертуар театра способствовала загадочная сценичность его повествования, отмечавшаяся исследователями неоднократно, хотя и не всегда доказательно» [Любимов: 10].

Ф. М. Достоевского не стало в 1881 г. Этот год - поворотный для русской критики, писавшей о нем: его образ и биография стали завершенным полотном, оценивать которое можно было уже не только с позиции сиюминутности, но и вечности.

Одним из первых обратил особое внимание на сценичность произведений Достоевского Д. С. Мережковский. Например, он писал о близости художественной системы Достоевского поэтике античной драмы, ведь «не только присутствие рока в событиях придает рассказу Достоевского трагический пафос в античном смысле слова - этому впечатлению способствует еще и единство времени (тоже в античном смысле)»³. Отмечает Мережковский и динамику, и насыщенную событийность произведений писателя: «В промежуток одного дня, иногда нескольких часов, события и катастрофы нагромождаются целыми массами. Роман Достоевского - не спокойный, плавно развивающийся эпос, а собрание пятых актов многих трагедий» ${ }^{4}$.

Позже критики, вслед за Мережковским, подчеркнут и сверхдраматизм произведений Достоевского, и тему фатума, и роковых страстей в судьбах его героев.

Вяч. Иванов дал романам Достоевского определение «романов-трагедий», утверждая, что трагичен, по существу, сам их поэтический замысел: «Роман Достоевского есть роман катастрофический, потому что все его развитие спешит к трагической катастрофе» ${ }^{5}$. И катастрофизм этот, по мнению Вяч. Иванова, проистекает из самой духовной жизни писателя, который, стоя на эшафоте и заглянув смерти в глаза, пережил духовное перерождение: «Мы видим, что идея вины и возмездия, эта центральная идея трагедии, есть и центральная идея Достоевского, все творчество которого, после Сибири, кажется одним художественным раскрытием и одним религиозным исповеданием единой мысли о единой дилемме человека и человечества: быть ли, т. е. с Богом, или не быть, т. е. мнить себя сущим - без Бога» ${ }^{6}$. 


\section{Периодика о первых опытах инсценировок: "Дядюшкин сон", "Село Степанчиково"}

В период с 1840-х до 1880-х гг., согласно библиографическому указателю С. В. Белова [Белов: 403-469], имя Достоевского в связи с театром упоминается в критике всего несколько раз. Например, в рубрике «Московская летопись» журнала «Москвитянин» за 1846 г. мы встречаем заметку В. В. Львова о чтениях актером М. С. Щепкиным письма из «Бедных людей» в доме С. Ю. Самариной.

В тот вечер Щепкин, помимо «Старосветских помещиков» Н. В. Гоголя и двух стихотворений Н. А. Некрасова, прочел отрывок из напечатанного в «Петербургском сборнике» романа Достоевского «Бедные люди». Критик газеты «Москвитянин» пишет об этом следующее: «...вечер был не совсем удачен <...> Одно письмо из “Бедных людей” Достоевского прочтено им $<$ Щепкиным> было лучше. Но зачем читал он его? Г-н Достоевский имеет неотъемлемые достоинства: глубокий взгляд, глубокое знание сердца человеческого, мастерскую кисть, и сцена Девушкина перед добрым начальником верна, слова нет, но дело не в одной верности только, дело в выборе того, что дагеротипировано; прекрасно нарисованная картина не всегда найдет себе приличное место на стене богатой гостиной» 7 .

Начало же сценической биографии Достоевского было положено лишь в 1878 г., когда по мотивам повести «Дядюшкин сон» Л. Н. Антропов написал комедию «Очаровательный сон». «В 1882 г. эта повесть была по-новому интерпретирована в Петербургском русском театре, а в 1891 г. К. С. Станиславский инсценирует и ставит “Фому” (по роману “Село Степанчиково и его обитатели”) на сцене Московского общества искусства и литературы. Затем появляются спектакли по романам Достоевского: в императорских театрах ставится “Идиот", в театре Литературно-художественного общества “Преступление и наказание” и, наконец, в 1900 г., в гастрольном спектакле известного актера П. Н. Орленева, — “Братья Карамазовы” [Сокурова: 123].

Проанализируем критику 1880-х гг., посвященную постановке комедии «Дядюшкин сон» на сцене Русского театра в Петербурге (художественным руководителем которого был на тот момент Д. Д. Коровяков $\left.{ }^{8}\right)$. Сразу три крупных газеты написали о премьере 1882 г.: «Новое время»" «Голос» и «Биржевые ведомости».

В разделе «Театр и музыка» газеты «Новое время» $(1882,9$ дек.) критик пишет о том, что представленный на сцене «Дядюшкин сон» вышел не комедией, а рассказом в разговорной форме, который может смотреться с удовольствием только в мастерском исполнении.

Подробно анонимный критик останавливается на актерском составе. На сцене Русского театра роль князя играл г. Борисовский — «даровитый актер». В роли Зины - г-жа Н. Абаринова, молодая актриса, «обладающая эффектной сценичной наружностью». В маленькой роли Натальи Дмитриевны выделилась 
г-жа Милова, а актрисе Дубровской, исполнившей одну из главных ролей, практической дамы Москалевой - «можно пожелать более рельефной игры и поменьше однотонности» ${ }^{10}$.

В разделе «Хроника» петербургской газеты «Голос» $(1882,8$ дек.) также выходит заметка об этой постановке. «Вчера в Русском театре была дана незнакомая петербургской публике, но уже несколько лет с успехом играющаяся в провинции трехактная комедия “Дядюшкин сон”»"11, - предваряет критик свою статью, из которой мы узнаем, что комедия, оказывается, давно идет в провинции и только сейчас дошла до Петербурга.

Автор заметки, как и предыдущий критик, размышляет о жанре постановки: «...в пьесу эту перешел юмор покойного писателя. Он-то и составляет, при некой бедности ее содержания, главное ее достоинство» ${ }^{12}$.

Газета «Биржевые ведомости» $(1882,14$ дек.) также публикует отзыв о премьере в Русском театре. Критик Еф. А. пишет о том, что повесть «Дядюшкин сон» - одно из самых слабых произведений Достоевского и в переделке представляет очень незавидную по сценичности и по новизне комедию.

Главные же достоинства героев Достоевского - психологическая верность и тонкость, по мнению критика, не проявляются в комедии: «Действующие лица выходят ходульными и водевильными и не представляют ничего сценически эффектного» ${ }^{13}$.

Рассуждая о жанровой специфике постановки, автор отмечает, что «несмотря на чисто водевильный характер комедии, в ней проглядывает местами мастерская рука маститого писателя» ${ }^{14}$

Что касается актерской игры, то, как и критик газеты «Голос», автор «Биржевых ведомостей» пишет, что роль князя, которую взял на себя сам режиссер, он «постыдно провалил», а из всех исполнителей одна г-жа Абаринова была прилична.

В 1891 г. К. С. Станиславский предпринял постановку спектакля «Фома» по роману Достоевского «Село Степанчиково» - написал инсценировку, стал режиссером и сыграл одну из заглавных ролей. Это был один из его первых сценических опытов в кружке любителей драматического искусства при Обществе искусства и литературы.

На эту постановку появилось всего два отзыва: в журналах «Артист» и «Развлечение».

Критик С. на страницах «Артиста» называет эту постановку творческой удачей и, что особенно важно, отмечает ее близость оригинальному тексту Достоевского: «Дух рассказа Достоевского сохранен в полной неприкосновенности; большею частью даже сохранен его слог, и Станиславскому (автору переделки) совершенно несправедливо делали упреки за то, что будто бы им слабо передан язык эпохи» ${ }^{15}$. Критик, напротив, полагает, что точность в передаче эпохи, к которой относится происходящее на сцене, - это первое, что бросается в глаза, начиная с архитектуры, комнат и убранства $30-$ х годов 
и заканчивая костюмами. Все это, по словам автора, производит «цельное и гармоничное впечатление, какого зритель не получал даже и на сцене Малого театра» ${ }^{16}$.

Говоря об актерском мастерстве, рецензент отмечает работу Станиславского, называя ее лучшей в этом спектакле: «Бесхарактерный полковник в его исполнении живет на сцене с поразительной правдивостью, и вы минутами готовы поверить, что перед Вами не актер, а сам полковник, то очаровательный в своей непомерной доброте, то до отвращения тряпичный... Без искры истинного таланта этого не заставишь почувствовать никакою игрою» ${ }^{17}$.

Завершая статью, критик заключает, что на сцене были показаны психологически достоверные человеческие типы героев, которые актуальны во все времена, потому как «они жили всегда и умрут с человечеством» ${ }^{18}$ и что каждая сцена в этой постановке - это выхваченная из жизни картинка.

Рецензент журнала «Развлечение» С. Никонов размышляет о том, что переделать рассказ в драматическое произведение, сохранив при этом целостность оригинала, практически невозможно: «Драматические произведения, по самому существу своему, глубоко разнятся ото всякого другого рода литературных работ не только способом изложения, формою, но и течением действия...»19. Именно поэтому, переделывая рассказ в пьесу, недостаточно просто перенести туда диалоги персонажей. Требуется также привнести движение действующих лиц, выразить все идеи и все содержание, заложенное в рассказе.

Критик утверждает, что создатель инсценировки должен вступить в творческое соавторство с создателем прозаического произведения: «...словом, переделыватель должен явиться самостоятельным автором, стать в уровень с тем, у кого заимствует, смотреть его глазами и, кроме того, в случае надобности дополнить движение типов и действие пьесы сценами, не идущими вразрез с мыслью автора» ${ }^{20}$.

Отмечая недостатки постановки, рецензент все же высоко оценивает актерское мастерство К. С. Станиславского, исполняющего роль Егора Ильича: «Станиславского я видел всего в первый раз и должен сознаться, что жалею, что ранее мне не удалось ознакомиться с ним, как артистом. В роль Ростанева он вложил такую массу таланта, был так прост, так естественен, что положительно являл собой живой образ» ${ }^{21}$.

Этот спектакль, таким образом, стал одним из первых подступов Станиславского к инсценировкам произведений Достоевского.

\section{Роман «Преступление и наказание» на российской и зарубежной сиене}

В декабре 1871 г. В. Д. Оболенская ${ }^{22}$ писала письмо Ф. М. Достоевскому с просьбой о дозволении переделать «Преступление и наказание» в драму для представления на Императорских театрах. На что Достоевский ответил: «Есть какая-то тайна искусства, по которой эпическая форма никогда не 
найдет себе соответствия в драматической. <...> Другое дело, если Вы как можно более переделаете и измените роман, сохранив от него лишь один какой-нибудь эпизод, для переработки в драму, или, взяв первоначальную мысль, совершенно измените сюжет?... ${ }^{23}$.

В следующий раз сцена из романа будет представлена в переделке АндрееваБурлака в первом частном театре России ${ }^{24}$ в 1883 г. Остальные попытки инсценировать этот роман, включая первую - Ушакова (1867), — не были приняты цензурой.

Как видим, сценическая история романов Достоевского формировалась уже после смерти писателя. Все дело в том, что «цензурные органы с большим упорством и последовательностью препятствовали проникновению на сцену театра произведений Достоевского, усматривая в них “сплошной протест против существующего общества”» [Орнатская, Степанова: 269].

До нас дошли протоколы двух заседаний Совета Главного управления по делам печати, на которых рассматривалась пьеса Ушакова ${ }^{25}$. Скажем, в протоколе записано: «Ввиду такого неудовлетворительного исхода пьесы, отсутствия в ней торжества жизненной правды и нравственных начал, цензор не находит удобным дозволить оную к представлению на сцене» [Орнатская, Степанова: 270]. Так, все старания и ходатайства Ушакова о цензурном разрешении своей инсценировки на протяжении долгих пятнадцати лет оказались безрезультатными.

В итоге «...более трех десятилетий попытки добиться разрешения постановки инсценировок “Преступления и наказания”, хоть в какой-то мере близких к роману Достоевского, были тщетными. И лишь искажение содержания и идей произведения великого писателя, на которое пошел Я. Дельер, устроило вершителей театральной политики» [Орнатская, Степанова: 275].

Заметной и обсуждаемой в прессе стала инсценировка романа в 1888 г. на сцене парижского театра «Одеон» (режиссеры - Поль Жинисти и Гюг Леру). Оговоримся, что это была первая известная нам зарубежная постановка романа «Преступление и наказание». Перевод был осуществлен французским литератором Виктором Дерели, который впоследствии перевел и другие романы Достоевского ${ }^{26}$.

Критик И. Яковлев в газете «Новое время» анализирует инсценировку с точки зрения художественного воплощения замысла Достоевского и точности передачи страстей, которыми одержимы герои его произведений.

«Как передать своеобразность этого нервного стиля, гениальный анализ сложных, тонких и запутанных психологических состояний его измученных и больных героев? $\rangle^{27}$, - спрашивает И. Яковлев. Ведь сама основа его произведений заключена в том, что «постепенность развития страстей важнее самих страстей. Но на сцене такой анализ невозможен» ${ }^{28}$.

Критик отмечает смелость режиссеров, которые поставили не всю драму целиком, а ряд картин, взятых из романа, точнее семь картин в семи актах. 
Переделанный для сцены роман теряет свою психологическую глубину, однако сама инсценировка, по мнению критика, сделана «умело, умно и смотрится с интересом» ${ }^{29}$.

Через несколько дней рецензия на этот спектакль появляется и в газете «Русские ведомости». Мнение критика К. В. Аркадакского во многом совпадает с И. Яковлевым.

Вердикт обоих критиков таков: невозможно перенести на сцену психологический анализ романов Достоевского. Ведь «малейшее непонимание в развитии того душевного процесса, который довел героя сначала до преступления, а потом до раскаяния - и драма "Преступление и наказание" потеряет всю свою оригинальность» ${ }^{30}$.

Критик утверждает, что постановщики не поняли характера Раскольникова и не проследили развитие драмы в его душе. Автор рецензии высказывает претензии и актеру Полю Мунэ, который «не сумел уловить той тонкой черты, которая отделяла его героя от сумасшествия: в первых двух действиях он предстает прямо-таки маньяком в последней степени развития болезни»

Меж тем, из инсценировки выброшены такие важные персонажи романа, как Свидригайлов, сестра Лизавета, мать Раскольникова, которые создают объем произведения и оттеняют черты характера самого Раскольникова.

Порфирий же, по мнению критика, и вовсе предстает «простым вульгарным сыщиком». Роман, таким образом, «исковеркали и обезобразили». А для публики, которая не читала оригинал, «драма предстает скучной и убийственно мрачной, в отсутствие сложной душевной драмы Раскольникова, которую режиссеры не сумели передать» ${ }^{32}$. Заканчивается статья словами критика о том, что этот роман претерпит еще много сценических переделок.

Вслед за парижской премьерой, в 1890 г., роман инсценировали в Германии. Были осуществлены сразу две постановки - в Лейпциге и в Берлине.

Лейпцигская постановка «Raskolnikow», по словам «Berlinez Tagblatt», проходит с большим успехом. А для спектакля в Берлине, который также идет с успехом в Лессинговом театре, «даже сделаны специальные декорации с видом Невского проспекта, для погружения зрителей в атмосферу романа Достоевского» ${ }^{33}$.

Спустя пять лет, в 1895 г., в Новом театре Берлина предприняли еще одну попытку инсценировать «Преступление и наказание». Более того, критик Е. Ш., отзыв которого приведен на страницах «Нового времени», считает эту постановку единственно удачным прочтением романа Достоевского на немецкой сцене.

По мнению Е. Ш., авторам сценической переделки удалось уложить этот шедевр психологического романа в узкие рамки сцены - да к тому же еще иностранной: «Хотя это и кажется на первый взгляд неподъемной задачей, г-н Цабель, знакомый русской публике по своему постоянному и дружелюбному стремлению популяризировать наших великих поэтов - лучше всякого 
другого мог понять эту невозможность» ${ }^{34}$. Меж тем, «...переделка, продолжает рецензент, - сделана искусно и занимательно» ${ }^{35}$.

Высоко оценивает критик и исполнительское мастерство. Настолько высоко, что даже восклицает: «Где взять прилагательные для похвалы г-жи Шрамм (закладчица), г-ну Матковскому (Раскольников) и Келлер (Порфирий). Это трио артистов выше всяких похвал!» ${ }^{36}$.

Возвращаясь к предыдущей постановке этого романа в Лессинг-театре, критик отмечает, что все безобразные ошибки в выборе декораций и реквизита были устранены.

Таким образом, Е. Ш. резюмирует, что Достоевский сумел привести холодную публику в восторг.

В России к постановке «Преступления и наказания» обратились в 1899 г. В петербургском Театре Литературно-художественного общества ${ }^{37}$. Сценическую версию представил известный драматург и литератор Дельер ${ }^{38}$. Заглавную роль Раскольникова исполнил ведущий актер Суворинского театра Павел Орленев.

Пресса встретила переделку настороженно. В газете «Сын Отечества» выходит статья критика А. А. Яблоновского, в которой он негативно высказывается о всякого рода переделках романов для сцены.

По мнению автора статьи, Дельер выхватил несколько самых драматических и эффектных сцен, бестолково перепутал их и, «спрятавшись за спину Достоевского», преподнес публике. В то время как сцены, которые при чтении их в романе захватывают дух своим высоким драматизмом, при воплощении на сцене вызывают хохот зрителей.

Завершает статью критик тем, что сетует на то, что, к сожалению, ни закон, ни общество не придумали еще средства, с помощью которого можно было бы «оградить художественное достояние нации от посягательств» ${ }^{39}$.

Отметим, что с момента смерти писателя прошло почти два десятилетия, и критики уже называют его национальным достоянием. Думается, что инсценировки его произведений, как удачные, так и спорные, отчасти этому поспособствовали, заложив традицию постановок прозы Достоевского и дав возможность зрителям познакомиться со сценическим эквивалентом.

Серьезное осмысление эта же постановка получила в журнале «Театр и искусство». Критик Н. М. Ежов предваряет статью размышлениями, традиционными для авторов, пишущих о Достоевском, - о сложности перенесения романного текста на театральные подмостки: «Роман нуждается в совершенно других элементах, чем драма. <...> Такая переделка может быть исполнена хорошо только самим автором» ${ }^{40},-$ размышляет критик. Особенно крупные затруднения в этом отношении представляет, по его мнению, творчество Достоевского, поскольку его действующие лица в основном сильны и живы своей сущностью, а не какими-либо внешними признаками. 
Между тем, Дельер, по мнению Н. М. Ежова, со своей задачей справился, поскольку «пьеса произвела на публику впечатление глубокое. <...> в пьесе много хороших ролей, доставивших талантливым исполнителям успех» ${ }^{41}$.

Критик Б. И. Бентовин подчеркивает огромный зрительский и читательский интерес к этой постановке, так как все билеты не только на первое, но и на второе представление были распроданы, а в пяти библиотеках не нашлось ни одного свободного экземпляра книги.

По мнению критика, в пьесу включены сцены, в которых очень трудно удержаться от соблазна, чтобы не перейти на почву психопатизма: «Такова картина 7-я, вторая встреча с Порфирием Петровичем. Г-н Орленев ведет финал этой сцены замечательно сильно, ярко, энергично, но в кликушество ни на минуту не впадает. И здесь Орленев достигает потрясающего эффекта, ведя всю сцену просто, не форсируя, не ударяясь в область истерии. За такое олицетворение Раскольникова - г-ну Орленеву большое спасибо» ${ }^{42}$.

В целом автор рецензии полагает, что эта постановка делает честь режиссеру театра, так как все в ней продумано до мелочей (от декораций до костюмов), все художественно-реально слажено и отражает сложный мир романа Достоевского.

Чтобы оценить полемику в прессе по поводу инсценировки авторства Дельера и понять, насколько она близка к оригиналу, мы обратились в архив ГЦТМ им. А. А. Бахрушина. Так, изучив суфлерский экземпляр, можно сделать следующие выводы. Во-первых, в тексте отсутствует такой важный персонаж как Свидригайлов. Во-вторых, отсутствует эпилог романа. Инсценировка заканчивается разговором Сони и Раскольникова, финальные слова которого звучат так:

«Раскольников. О, как я вас всех ненавижу. Пойду, отдамся ему один. $\kappa$ чему тут иелая свита.

Занавес» ${ }^{43}$.

То есть момент признания Раскольникова в преступлении Илье Петровичу (помощнику квартального надзирателя) также отсутствует.

Таким образом, отзывы критиков о значительном изменении оригинального текста были небезосновательны.

В 1900 г. прошли гастроли Суворинского театра с этим спектаклем. В газете «Новое время» выходит статья, посвященная гастролям, идущим «с блестящим материальным успехом» ${ }^{44}$. Как отмечается в публикации: три спектакля в Москве дали сбор в 1800 рублей, а последующие представления в Туле, Орле, Харькове, Полтаве, Кременчуге - более 1100 рублей за каждое.

Редакция газеты «Новое время» приводит на своих страницах и реплики авторов других газет. Думается, это означает то, что редакторы газеты осознают значимость инсценировок романов Достоевского не только в России и за рубежом, но и в провинции. 
Так, харьковская газета «Южный край» находит, что Орленев прочувствовал и выстрадал роль Раскольникова. Подкупает зрителя искренность тона, необыкновенная нервность и изумительная мимика. Особое впечатление произвела сцена объяснения с Соней, в роль которой «внесла много сердечности и непосредственной простоты г-жа Погодина. Актер Яковлев убедителен в роли Порфирия Петровича» ${ }^{45}$.

Эти гастроли не оставили равнодушным и критика газеты г. Керчь «Южный курьер», который, несмотря на их успех, полагает, что создатель инсценировки, кто бы он ни был и какими великодушными поступками он не руководствовался - желанием ли познакомить публику с произведением или другими побуждениями, - «должен быть заклеймен общественным презрением» ${ }^{46}$, поскольку смеет не только посягать на классику, но и вольно ее интерпретировать.

Однако он отмечает, что Орленев играет точно по Достоевскому и проявляет тонкое артистическое чутье. Актер, по его словам, из этого тяжелого испытания вышел победоносно. Публика встречает его овациями: «Зал аплодировал ему за умение слушать, за умение без слов выражать свою душевную скорбь, за умение высказывать сострадание, участие, жалость и любовь, не проронив ни одного слова, одними только взглядами, мимикой, выражением лица $<\ldots>$ Он весь соткан из нервов» ${ }^{47}$.

Видимо, этот пример вдохновил и режиссера города Уральска Викторова на создание инсценировки по мотивам этого же произведения, которая и была представлена в местном театре силами местной труппы. В газете «Уралец» незамедлительно отреагировали на этот опыт. «Переделка романа оказалась много удачнее других переделок подобного рода» ${ }^{48},-$ пишет корреспондент «Уральца», однако отмечает, что желание как можно полнее передать содержание романа сделало переделку слишком длинной: спектакль был окончен только к двум часам ночи. К тому же, сложно выдержать нервное напряжение, нарастающее на протяжении всей постановки. Но в целом, эту инсценировку, по мнению автора «Уральца», можно считать состоявшейся.

\section{Полемика вокруг инсценировки романа «Идиот»}

В 1899 г. первую постановку романа «Идиот» осуществил московский Малый театр и параллельно Александринский петербургский театр (авторы инсценировки для обоих театров - Крылов ${ }^{49}$ и Сутугин ${ }^{50}$ ). Литературнокритические статьи носили полемический характер - от неприятия до суждений о том, что впервые был найден и воплощен сценический образ прозы Достоевского.

Уже на следующий день после постановки в газете «Московские ведомости» в разделе «Театр и музыка» появилась заметка о том, что спектакль прошел с большим успехом, были проданы все билеты, а «исполнение сопровождалось 
горячими аплодисментами обычно сдержанной публики» ${ }^{51}$. И это была едва ли не единственная положительная рецензия на спектакль.

Главную роли Настасьи Филипповны исполняла М. Н. Ермолова (в роли Аглаи выступила А. А. Яблочкина). Отношение М. Н. Ермоловой к творчеству Достоевского не было однозначным. Как отмечает Т. Л. Щепкина-Куперник, она его «признавала гениальным, но долгие годы ей было мучительно его читать. Ее отталкивало то, что Достоевский, заставляя своих героев страдать, не дает им никакого выхода, а это никак не вязалось с требованиями, которые М. Н. Ермолова предъявляла к искусству» ${ }^{52}$.

Критики не оценили ни актерскую работу Ермоловой, ни постановку в целом. В газете «Русский листок» появляется разгромная рецензия критика М. Оликова, в которой он сетует на то, что «постановщики без толку понадергали цитат из романа, связали их белыми нитками, присочинили безграмотный и грубый конец, и эту скверную стряпню преподнесли публикељ\%

По мнению автора рецензии, Крылов и Сутугин на первый план выдвигают мотив соревнования Настасьи Филипповны и Аглаи, что не совсем верно. И даже талантливый актер Васильев не исправляет положение, так как «личность князя туманно и слабо охарактеризована Крыловым и Сутугиным» ${ }^{54}$.

Настасье Филипповне в исполнении Ермоловой дана такая характеристика: «Великолепная фигура Настасьи Филипповны, чистой женской души, загаженной и изломанной скверным сластолюбцем, нашла себе отличную истолковательницу в лице М. Н. Ермоловой. Правда, Настасья Филипповна должна быть значительно моложе, чем изображает ее Ермолова, но что же тут поделаешь?» ${ }^{55}$. Напомним, что Ермоловой на момент исполнения роли было 46 лет.

Сразу после премьеры Ермолова пишет в письме к Л. В. Середину следующие строки: «Пишу вам под тяжелым впечатлением. Вчера сыграли “Идиота" и ничего, так-таки ничего. Публика холодна и сдержанна... в чем дело понять не могу, но огорчена я была страшно, я говорила, что я никуда не годная актриса, что мне надо бросать сцену и т. д. Одним словом, вела себя “по-идиотски"... Наутро я немножко опомнилась» ${ }^{56}$.

Анна Григорьевна Достоевская в своем «цензорском попечении» сетует на то, что она страдала на представлении «Идиота» в Московском театре, слыша отзывы публики: «Нет, это не Достоевский, это черт знает что! Ведь можно так испортить Достоевского? Пропал мой любимый роман» [Волгин].

Не обошли эту постановку и театральные журналы, на страницах которых она получила более подробный разбор. Критики писали не только о качестве самой инсценировки и актерских работах, но и о декорациях и костюмах. Сразу в двух номерах журнала «Театр и искусство» за 1899 г. выходят рецензии на московского «Идиота».

Казалось бы, начало первой публикации обнадеживает: «Пьеса не так слаба, как стараются выставить некоторые рецензенты. Первые три акта смотрятся с захватывающим интересом. Достоевский в них соблюден в достаточной 
степени» ${ }^{57}$, - пишет критик. Но потом сам же и разносит постановку, особенно пятый акт, который называет нелепым, поскольку «вместо человеческого финала Достоевского, г-н Крылов заставляет князя Мышкина говорить какой-то монолог, надерганный автором из разных немецких пьес, которые всю свою жизнь он ловко перекраивал. Г-н Крылов любит подправлять авторов. Это черта его самонадеянности» ${ }^{58}$.

А. Р. Кугель, опубликовавший свою рецензию на эту же постановку в одном из последующих номеров журнала «Театр и искусство» был не так категоричен в своих высказываниях. На его взгляд, создатели переделки, напротив, взяли материал почти прямо, без изменений: «Обвинения авторов в том, что они ввели в пьесу много своего - неосновательны. Напротив того, они крайне осторожно и осмотрительно допустили изменения, которые требовали условия сцены» ${ }^{59}$.

Автор находит, что актер Васильев в роли Мышкина был неубедителен, поскольку «эта роль ему еще не по плечу». Но больше всего критики опятьтаки в адрес Ермоловой: «При всем глубочайшем уважении к таланту этой артистки, приходится сказать, что она менее всех остальных исполнителей соответствует этому образу Настасьи Филипповны, которая так ярка и колоритна» ${ }^{60}$. Были высказаны претензии и к декорациям (салон Настасьи Филипповны напомнил автору рецензии декорации «Травиаты»), и к костюмам (все персонажи были выведены в современных костюмах, что «не вяжется со многими местами текста») ${ }^{61}$.

Говоря о такой важной составляющей, как заполняемость зала, критик отметил, что уже на втором и третьем показе было значительное количество пустых мест. Все эти замечания представляют интерес, поскольку не только воссоздают образ спектакля, но и акцентируют внимание на любопытных деталях театральной жизни тех лет.

Гневно высказался в адрес создателей инсценировки и автор отзыва в журнале «Русская мысль», с самого начала заявивший, что «все, что есть в спектакле хорошего, принадлежит Достоевскому, а все неудачное - авторам переделки» ${ }^{62}$. Хотя именно этот критик оказался одним из немногих, кто поддержал актрису Ермолову: «Данные таланта г-жи Ермоловой говорят за то, что исполнение ею роли Настасьи Филипповны может дойти до высокой степени нервного подъема» ${ }^{63}$.

Об игре остальных исполнителей он отзывается нелестно, но считает, что смазанные характеры - вина не актеров, а создателей спектакля: «Авторы переделки из большинства действующих лиц драмы безжалостно вырезали ту душу, которую вложил им автор романа» ${ }^{64}$. Князь Мышкин, Ганя Иволгин, Аглая Епанчина, Парфен Рогожин, по мнению критика, изменены до неузнаваемости, и артисты, их изображающие, вынуждены бороться с непосильной задачей: заставить зрителей слушать их между строк и вспоминать образы изображаемых ими лиц теми фразами, мыслями и действиями, которые в драматической переделке упущены. 
В Александринском театре роль Настасьи Филипповны исполняла прима театра М. Г. Савина, до которой дошли слухи о провале московского спектакля, что ее несколько обескуражило. Накануне премьеры она даже писала: «До того это неладно и нескладно на сцене и так невыполнимо, что ужас берет» ${ }^{65}$. Роль Аглаи досталась другой приме - В. Ф. Комиссаржевской. К постановке Александринского театра в Санкт-Петербурге критика была благосклоннее. Более того, об этой инсценировке вышли отзывы даже в провинциальной прессе.

В газете «Гражданин» критик П. И. Вейнберг начинает свою статью со слов о маленькой победе Петербурга над Москвой и о том, что петербургский «Идиот» вышел много лучше московского и не только не провалился, но и имел крупный успех. «Дело в том, что вся петербургская труппа отнеслась к “Идиоту" старательнее московской, а главное - две центральные фигуры драмы (Настасья Филипповна и князь Мышкин) вышли у нас куда удачнее» ${ }^{66}$, пишет критик.

У Ермоловой, по его мнению, роль Настасьи Филипповны не задалась, в то время как для Савиной эта роль стала одной из лучших в ее карьере. Хвалит рецензент и актерскую работу Аполлонского, исполнившего роль князя Мышкина: «грим, тон, манера - все это он в Мышкине удивительно тонко выдержал и вкупе с Савиной создал успех пьесы» ${ }^{67}$.

В «Петербургской газете» А. Р. Кугель восторженно пишет о том, что постановка, в отличие от московской, его не разочаровала, а напротив, произвела даже более сильное впечатление, чем роман. «Густо написанное в романе стало еще гуще в пьесе; экстаз стал еще экстатичнее, надрыв еще надорваннее. Драматическое действие - при том довольно искусно слаженное - подобно прессу сжало роман, выпустив из него всю воду и оставив только то крепкое, нерастворимое, что составляло его потайную сущность» ${ }^{68},-$ считает А. Р. Кугель.

Отмечает критик и прекрасные актерские работы, которые «прочувствовали сущность Достоевского и усилили черты героев собственным талантом» ${ }^{69}$.

А. А. Измайлов в газете «Биржевые ведомости» высказывает мнение о том, что эта инсценировка представляется ему целостной драмой, а не простым лишь рядом случайных сцен. Все артисты, на его взгляд, были талантливы и органичны, а наиболее эффектными показались сцена бросания 100 тысяч в камин и сцена объяснения Аглаи и Настасьи Филипповны, в которой «г-жа Савина и г-жа Комиссаржевская возвысились до высокой художественности» ${ }^{70}$. По поводу остальных актерских работ написано следующее: «Сдержанно и с тактом был воплощен актером Аполлонским на сцене князь Мышкин. Спокойно и ровно изобразил Дальский Рогожина, сумев совершенно избежать театральности» ${ }^{71}$.

Показательны слова о том, что «нельзя не приветствовать новинки хотя бы просто потому, что она дает возможность восстановить в памяти одно 
из замечательных произведений родной литературы» ${ }^{72}$. Это подчеркивает, что образ Ф. М. Достоевского и его творчество все более входят в сознание как часть национальной культуры, ведь «он воплотил не только потаенные черты русского духа, но и драматический ход национальной истории» [Волгин].

Осип Дымов на страницах журнала «Театр и искусство» отмечает досадные неточности и расхождения текста романа с действом на сцене. Например, в спектакле князь Мышкин принят генералом в столовой, а не в кабинете (как у Достоевского), скомкана, на его взгляд, и значимая сцена с пощечиной. Эффектную сцену бросания в огонь 100 тысяч в оригинале «князь наблюдал грустно и молча», а в переделке князь подходит к Гане и уговаривает его не лезть за деньгами: «Этим искажается образ князя. Из тонкой, полной ужаса психологии вышло что-то водевильное и пошловатое» ${ }^{73}$. Расстраивает критика и вольное обращение постановщиков с важными художественными деталями: «В романе денежная пачка была завернута в “Биржевые ведомости” и обвязана туго-натуго со всех сторон бечевкой; на сцене - пачка обвернута синей толстой бумагой» ${ }^{74}$. Все это приводит к тому, что создается не совсем точный и психологически достоверный образ спектакля.

Добавим, что и конец инсценировки изменен, согласно экземпляру пьесы «Идиот», хранящемуся в архиве ГЦТМ им. А. А. Бахрушина. Так, в уста князя Мышкина вложены слова Мити Карамазова. Кроме того, в финале романа Достоевского князь и вовсе не произносит ни слова, в отличие от текста Крылова и Сутугина, который приведен ниже:

«Князь. Не подходите! Не подходите!.. Не пушу!.. Красота - это страшная сила!. Тут бог с дьяволом борется и поле битвы сердиа людей. Оставьте их, они добрые... Чистые сердием, младениьь, а? Господа, вы согласны бъть младенияами? (Вопросительно оглядывает всех). Что же вь мне не отвечаете?» ${ }^{75}$

Автор статьи в газете «Северный курьер» Н. А. Селиванов считает, что «Достоевский менее всего способен поддаваться драматической переделке. Это необычное по психологической глубине и ширине произведение заключает в себе двадцать, тридцать сюжетов, каждый из которых готов и может развернуться в драму, в сильную, потрясающую, очень редко примиряющую, потому что в каждой драме за человека становится или больно, или страшно» ${ }^{76}$.

Н. А. Селиванов находит художественные и логические провалы. Так, на его взгляд, в техническом исполнении пьеса сделана слабо. Первая часть романа занимает три больших акта, остальные части скомканы в двух последних актах: «От этих сокращений прежде всего пострадал Ганя: вместо яркого вышло лицо бледное, в высшей степени неясное. Его ужасная пощечина, 
данная князю, получила совсем иные смысл и освещение, так как сцены раскаяния Гани, прощения в пьесе нет» ${ }^{77}$.

Скомкан, по мнению критика, и образ Аглаи. Образы Лебедева и Коли совсем пропадают из пьесы, а Нина Александровна и Варвара выведены на сцене в одном лице Вари, которая говорит реплики и за себя, и за отсутствующую в пьесе мать. Рецензент единодушен с другими критиками, писавшими об инсценировке романа «Идиот» на сцене Александринского театра: образ Настасьи Филипповны - одна из самых удачных ролей Савиной, которая ближе всего замыслу Ф. М. Достоевского.

В провинциальной критике, как и в столичной, поднимается вопрос о драматическом потенциале романов Достоевского и о трудностях их воплощения на сцене.

В 1900 г. в городском театре города Уральска силами местной труппы была осуществлена постановка спектакля «Идиот», что вызвало объемную статью в газете «Уралец».

Автор статьи пишет больше о психологии героев романа, чем о самой постановке. Настасью Филипповну он называет падшей женщиной, сохранившей при всем своем падении душевную чистоту. Князю Мышкину дана очень точная характеристика: «...это какой-то человек не от мира сего, какое-то взрослое дитя, называющее все предметы их собственными именами, это - сама правда, сама любовь. Его любовь какая-то всеобъемлющая. Он еще более христианин, чем этого требует само Евангелие» ${ }^{78}$.

Актерское воплощение, по мнению критика, было на высоком уровне: «Глубоко-драматические моменты хорошо удались артистке Крельской (Настасья Филипповна). Она была очень хороша в сцене с Аглаей (Новгородская). Мы переживали тогда истинно эстетические минуты» ${ }^{79}$.

Подводя итоги, отметим, что большинство критиков сходилось во мнении, что произведения Достоевского имеют значимый вес в репертуаре театра, обладают несомненным драматургическим потенциалом и являются национальным достоянием, однако воплотить их на сцене - невероятно сложная задача, требующая полнейшего погружения в мир героев Достоевского.

Создатели инсценировок этого периода во многом интуитивно методом проб и ошибок, но способствовали зарождению «театра Достоевского».

\section{ПРИМЕЧАНИЯ}

* Исследование выполнено при финансовой поддержке Российского фонда фундаментальных исследований (РФФИ), проект № 18-012-90021 Достоевский.

1 Биография, письма и заметки из записной книжки Ф. М. Достоевского. СПб.: Тип. А. С. Суворина, 1883. С. 41. В первой полной публикации воспоминаний А. Е. Ризенкампфа см.: [Ризенкампф: 119, 125, 126, 128-129].

2 Незнакомец (Суворин А. С.). о покойном // Новое время. 1881. 1 (13) февраля. № 1771. С. 2. 3 Мережковский Д. С. Достоевский // Русское обозрение. 1890. Т. 2. Кн. 3. С. 155-186, под загл. «О “Преступлении и наказании” Достоевского». С. 164. 
4 Там же.

5 Иванов Вяч. Достоевский и роман-трагедия // Иванов Вяч. Борозды и межи. Опыты эстетические и критические. М.: Мусагет, 1916. С. 21.

6 Там же. С. 51.

7 М. Ж. (Львов В. В.). Московская летопись. Жизнь в Москве в апреле 1846 года // Москвитянин. 1846. № 5.30 мая. С. 242.

8 Коровяков Д. Д. - русский писатель, критик и театральный педагог, один из авторов Энциклопедического словаря Брокгауза и Ефрона.

9 Более подробную информацию о рецепции творчества Достоевского в газете «Новое время» и о взаимоотношениях с А. С. Сувориным см. в работе А. А. Прощенко.

10 Театр и музыка // Новое время. 1882. 9 дек. С. 3.

11 Хроника // Голос. 1882. 8 дек. С. 3.

12 Там же.

13 Театральные заметки // Биржевые ведомости. 1882. 14 дек. С. 2.

14 Там же.

15 С. Спектакль в зале немецкого клуба «Фома» // Артист. 1891. № 18, дек. С. 127.

16 Там же.

17 Там же.

18 Там же.

19 Никонов С. «Фома» г. Станиславского // Развлечение. 1891. № 47. 1 декабря. С. 14.

20 Там же. С. 15.

21 Там же.

22 Оболенская Варвара Дмитриевна - княжна, дочь министра гос. имуществ.

23 Письмо Ф. М. Достоевского В. Д. Оболенской. 20 января 1872 г. // Достоевский Ф. М. Полн. собр. соч.: в 30 т. Л.: Наука, 1986. Т. 291. С. 225.

24 Имеется в виду Товарищество артистов Пушкинского театра, впоследствии театр Корша.

25 Материалы хранятся в Российском государственном историческом архиве (РГИА) в Санкт-Петербурге.

26 В дальнейшем Дерели также перевел «Идиота», «Бесов» и «Бедных людей». Все эти книги в последующие годы были изданы издательством «Plon».

27 Яковлев И. Маленький фельетон // Новое время. 1888. 9 сент. С. 2-3.

28 Там же.

29 Там же.

30 Д-ч (Аркадакский К. В.). Преступление и наказание // Русские ведомости. 1888. 13 сент. C. $2-3$.

31 Там же.

32 Там же.

33 Новое время. 1890. 19 ноября.

Е. Ш. Еще раз Раскольников на немецкой сцене // Новое время. 1895. 11 апреля.

Там же.

Там же.

Другие названия: Суворинский театр, или Малый театр в Петербурге.

Настоящее имя - Яков Алексеевич Плющик-Плющевский. Действительный статский советник, тайный советник. Драматург, переводчик, театральный и музыкальный критик, юрисконсульт Министерства внутренних дел. Сотрудник газет: «Свет», «Новости», «Голос», «Новое Время» и «Театр и Искусство».

39 Яблоновский А. А. Отголоски дня // Сын Отечества. 1899. 16 октября. С. 2. 
40 Прозаик (Ежов Н. М.) об инсценировке романа «Преступление и наказание» в Театре Литературно-художественного общества // Театр и искусство. 1899. № 41. С. 712.

41 Там же.

42 Импрессионист (Бентовин Б. И.). Малый театр // Новости и биржевая газета. 1899. 7 окт. С. 13.

43 ГЦТМ им. А. А. Бахрушина, архивно-рукописный отдел (АРО), фонд № 421 Орленева П. Н. «Преступление и наказание», пьеса по роману Достоевского Ф. М. (суфлерский экземпляр) с пометками Орленева П. Н. 1899 г. Книга поступления (КП) 298029, ед. хр. 6, 99 л.

44 Новое время. 1900. 20 мая. С. 4.

45 Там же.

46 Южный курьер. 1901. 2 декабря. С. 3.

47 Там же.

48 Уралец. 1900. 30 ноября.

49 Крылов Виктор Александрович - русский драматург, один из авторов Энциклопедического словаря Брокгауза и Ефрона.

50 Сутугин Сергей (Этингер Осип Григорьевич) - писатель, театральный критик, автор инсценировок и переделок для театра.

51 «Идиот» в Малом театре // Московские ведомости. 1899. № 281. С. 5.

52 Щепкина-Куперник Т. Л. Из воспоминаний. М.: ВТО, 1959. С. 199.

53 Оликов М. Театр и музыка // Русский листок. 1899. 13 окт. С. 3.

54 Там же.

55 Там же.

56 Ермолова М. Н. Письмо Л. В. Середину от 12 окт. 1899 г. // Письма М. Н. Ермоловой. M.: BTO, 1939. С. 158.

57 Театр и искусство. 1899. № 42. С. 735.

58 Там же.

59 Старый театрал (Кугель А. Р.) // Театр и искусство. 1899. № 45. С. 793.

60 Там же.

61 Там же.

62 Русская мысль. 1899 год. № 11. С. 205.

63 Там же.

64 Там же.

65 Савина М. Г. Письмо А. Кони от 25 окт. 1899 г. // М. Савина и А. Кони. Переписка: 1883-1915. Л.; М.: Искусство, 1938.

66 Скептик (Вейнберг П. И). Вслух // Гражданин. 1899. 7 ноября. С. 7.

67 Там же.

68 Homo Novus (Кугель А. Р.). Театральное эхо // Петербургская газета. 1899. 5 октября. С. 4.

69 Там же.

70 Измайлов А. А. Александринский театр // Биржевые ведомости. 1899. 6 ноября. С. 3.

71 Там же.

72 Там же.

73 Дымов О. Спектакль «Идиот» Александринского театра // Театр и искусство. 1899. № 46. C. 810

74 Там же.

75 ГЦТМ им. А. А. Бахрушина, архивно-рукописный отдел (АРО), фонд № 58536 Леонидова (Бермана Л. Д.). Инсценировка романа Достоевского Ф. М. «Идиот», сезон 1899-1900 гг. Малый театр. Книга поступления (КП) 316558/39, ед. хр. 36, 102 л. 
Селиванов Н. А. Театр и музыка // Северный курьер. 1899. 6 ноября. С. 3.

Там же.

А. А. «Идиот» в городском театре // Уралец. 1900. 19 октября.

Там же. 26 октября.

\section{СПИСОК ЛИТЕРАТУРЫ}

1. Бэлнеп Р. Л. Генезис романа «Братья Карамазовы». Эстетические, идеологические и психологические аспекты создания текста / пер. с англ. Л. Высоцкого. - СПб.: Академический проект, 2003. - 264 с. (Современная западная русистика; т. 45)

2. Белов С. В. Ф. М. Достоевский. Указатель произведений Ф. М. Достоевского и литературы о нем на русском языке, 1844-2004 гг. - СПб.: Российская национальная библиотека, 2011. - 755 c.

3. Волгин И. Л. Остановите Парфена (О фильме «Идиот» В. Бортко) [Электронный pecypc] // Официальный сайт «Игорь Волгин». — URL: http://www.volgin.ru/public/898. html (25.12.2018) (опубл.: Литературная газета. - 2003. - № 23-24. - 11 июня).

4. Любимов Б. Н. о сценичности произведений Достоевского: лекция по курсу «История русского дореволюционного и советского театра» для студентов театральных вузов. М: ГИТИС, 1981. - 62 с.

5. Орнатская Т. И., Степанова Г. В. Романы Достоевского и драматическая цензура (60е годы XIX - начало XX в.) // Достоевский. Материалы и исследования. - Л.: Наука, 1974. - T. 1. - C. 268-285.

6. Прощенко А. А. «Достоевец» Суворин: от противоборства к сближению» // Неизвестный Достоевский. - 2019. - № 2. - С. 149-170 [Электронный pecypc].— URL: http:// unknown-dostoevsky.ru/files/redaktor_pdf/1562686094.pdf (25.12.2018).

7. Ризенкампф А. Е. Воспоминания о Федоре Михайловиче Достоевском. Первая полная публикация / подгот. текста, вступ. ст. и примеч. Б. Н. Тихомирова // Достоевский и мировая культура. Альманах № 36. - 2018. - С. $103-158$

8. Сокурова О. Б. Сценическая история «Братьев Карамазовых»// Вестник СПбГУ. - Сер. 2. - Вып. 2. - 2010. - Июнь. - С. 123-132.

Alina V. Burmistrova

A. M. Gorky Institute of World Literature, the Russian Academy of Sciences

(Moscow, Russian Federation)

alina-art@autorambler.ru

\section{Dostoevsky's Novels on the Stage (Experience of the 1st Presentations)}

Acknowledgments. The reported study was funded by RFBR, project number 18-012-90021 Dostoevsky.

Abstract. The problem of origin and development of the so-called Dostoevsky theatre is the problem under consideration in this article. The study is based on a comprehensive research of the metropolitan and provincial periodicals about the staging of Dostoevsky's novels and their acceptance in 1880s-1890s. Many of the articles not studied by the researchers earlier are dedicated 
to the performability of the writer's novels. The review and analysis of these sources being introduced into scientific discourse for the first time make the originality of the work. Of particular interest are the materials from the archiCves of the State Central Theatre Museum named after A. A. Bakhrushin, a promptbook of the staged version of the novel "Crime and Punishment" by Delier and the play by Krylov and Sutugin based on the novel "The Idiot" for its staging in The Maly Theatre in Moscow and The Alexandrinsky Theatre in St. Petersburg.

Keywords: Dostoevsky, theatre, staging, acceptance, tradition, periodicals, criticism, archive

About the author: Burmistrova Alina V. - PhD in Philology, A. M. Gorky Institute of World Literature of the Russian Academy of Sciences (ul. Povarskaya, 25a, Moscow, 121069, Russian Federation), Correspondent of the Newspaper of the Union of Cinematographers "SK-Novosti" (ul. Vasil'evskaya, 13, str. 1, Moscow, 123056, Russian Federation)

Received: January 17, 2019

Date of publication: September 14, 2019

For citation: Burmistrova A. V. Dostoevsky's Novels on the Stage (Experience of the 1st Presentations). In: Neizvestnyy Dostoevskiy [The Unknown Dostoevsky], 2019, no. 3, pp. 96-115. DOI: 10.15393/ j10.art.2019.4021 (In Russ.)

\section{REFERENCES}

1. Belnep R. L. Genezis romana «Brat'ya Karamazovy». Esteticheskie, ideologicheskie i psikhologicheskie aspekty sozdaniya teksta [The Genesis of the Novel "The Brothers Karamazov". Aesthetic, Ideological and Psychological Aspects of the Text Creation]. St. Petersburg, Akademicheskiy proekt Publ., 2003. 264 p. (Ser. "Modern Western Russian Studies”; vol. 45). (In Russ.)

2. Belov S. V. F. M. Dostoevskiy. Ukazatel' proizvedeniy F. M. Dostoevskogo i literatury o nem na russkom yazyke, 1844-2004 gg. [F. M. Dostoevsky. Index of the Works of F. M. Dostoevsky and Literature About Him in the Russian Language, 1844-2004]. St. Petersburg, Rossiyskaya natsionalnaya biblioteka Publ., 2011. 755 p. (In Russ.)

3. Volgin I. L. Stop Parfyon (About the Film “The Idiot” by V. Bortko). In: Literaturnaya gazeta, 2003, no. 23-24. June 11. Available at: http://www.volgin.ru/public/898.html (accessed on December 25, 2018). (In Russ.)

4. Lyubimov B. N. O stsenichnosti proizvedeniy Dostoevskogo: lektsiya po kursu «Istoriya russkogo dorevolyutsionnogo i sovetskogo teatra» dlya studentov teatral'nykh vuzov [About the Staginess of Dostoevsky's Works: Lecture on the Course of History of Russian Pre-Revolutionary and Soviet Theatre for the Students of Theatre Universities]. Moscow, Russian Institute of Theatre Arts Publ., 1981. 62 p. (In Russ.)

5. Ornatskaya T. I., Stepanova G. V. The Dostoevsky's Novels and Drama Censorship (From the 1860 s Until the Beginning of the 20th Century). In: Dostoevskiy. Materialy $i$ issledovaniya [Dostoevsky. Materials and Researches]. Leningrad, 1974, vol. 1, pp. 268-285. (In Russ.)

6. Proshchenko A. A. "Dostoevets" Suvorin: From the Confrontation to Repprochement. In: Neizvestnyy Dostoevskiy [The Unknown Dostoevsky], 2019, no. 2, pp. 149-170. Available at: http://unknown-dostoevsky.ru/files/redaktor_pdf/1562686094.pdf (accessed on December 25, 2018). (In Russ.)

7. Rizenkampf A. E. Memories of Fedor Dostoevsky. The First Full Publication. In: Dostoevskiy i mirovaya kul'tura. Al'manakh № 36 [Dostoevsky and World Culture. Almanac no. 36], 2018, pp. 103-158. (In Russ.)

8. Sokurov O. B. A Stage History of “The Brothers Karamazov”. In: Vestnik Sankt-Peterburgskogo gosudarstvennogo universiteta. Ser. 2 [Vestnik of Saint-Petersburg University. Ser. 2], 2010, issue 2, June, pp. 123-132. (In Russ.) 